Katarzyna Klimek

https://orcid.org/0000-0001-9951-9264

Cracow University of Economics

Tourism Department

Faculty of Tourism

kklimek@uek.krakow.pl

\title{
THE IMPLEMENTATION OF "THE ST. GALLEN MODEL FOR DESTINATION MANAGEMENT (SGDM)" IN THE POLISH CARPATHIANS: A CASE STUDY OF SIX BIESZCZADY COMMUNES
}

\begin{abstract}
The Bieszczady mountains are one of the ranges of the Polish Carpathians. Their natural and cultural amenities attract thousands of Polish and international tourists each year. Despite many protected zones existing in this area (e.g. Bieszczadzki National Park, UNESCO Biosphere Reserve and Nature 2000 areas), the Bieszczady mountains face various environmental and social problems which have arisen from their dynamic but often chaotic tourism development. The lack of a common vision of long-term tourism development (on communal and regional levels) is one of the main challenging issues which public and private bodies are confronted with. The paper presents the results of the implementation of an innovative approach, i.e. the St. Gallen Model for Destination Management (SGDM), in selected Bieszczady communes. This method offers a clear advantage for key destination actors by allowing them to enter a process of holistic destination management. The article is the first attempt at SGDM application in Poland.
\end{abstract}

Keywords: mountain destination, holistic tourism development, SGDM model.

\section{INTRODUCTION}

Mountains are one of the world's key tourism reception areas and it is assumed that they take second place in global popularity after coastal regions (Nestorosk, 2012). The proportion of tourists visiting mountain destinations each year is estimated at 15 to $20 \%$ of total tourist numbers (Debarbieux, Oiry Varacca, Rudaz, Maselli, Kohler, Jurek, 2014).

Globalization with its associated tendencies towards integration of services and concentration of capital has put pressure on nature-based tourism destinations to improve their tourist offers in a highly competitive market either by cost leadership or product differentiation (Baker, Cameron, 2008; Baggio, Scott, Cooper, 2010). In response to this development, holistic management of tourism reception areas and sustainable use of resources have become subjects of growing importance, especially for many European mountain tourist areas (Klimek, Doctor, 2018).

The Bieszczady mountains, situated at the extreme south-east of the Polish Carpathians, constitute one of the most beautiful and wild parts of Eastern Poland. Among many natural attractions (e.g. the varied topog- raphy, scenic beauty, and rare fauna and flora species) this mountain region offers visitors rich cultural and historical assets. In 2017 the Bieszczady was visited by 464,000 Polish and international tourists and visitor numbers are increasing each year (US, 2018). However, a rapid and sometimes uncontrolled tourism development in this destination has caused many environmental and social problems (Świgost, 2017). Moreover, the lack of a common vision of both public and private stakeholders regarding tourism development in the Bieszczady region leads to frequent conflicts and a fragmented supply chain (Czernek, 2012). Thus, the holistic and sustainable governance of this area have become key conditions for its long-term and sustainable development.

The fundamental objective of this paper is to present the result of the application of the St. Gallen Model for Destination Management (SGDM model) in six Bieszczady communes. The paper offers a detailed description of the whole approach which was implemented in the Polish mountains for the first time in November and December 2018. 


\section{LITERATURE REVIEW}

Defining a tourism destination is challenging as there is an absence of a common and shared vision on this issue. For this reason, scholars and academics have defined a tourism destination starting from different points of view. Destinations have been, for example, defined as geographically delimited, supply-dominated areas where tourists travel to or decide to stay in (Bieger, Freyer, 2005; Kim, Richardson, 2003; Pearce, 1995 ).

However, many authors emphasize the fact that a tourist destination is more than a geographical place (Bieger, Beritelli, Laeasser, 2009; Haugland, Ness, Grønseth, Aarstad, 2011). It is an amalgamation of direct and indirect amenities, e.g. accommodation, catering, public and private transport and roads, visitor information, recreation facilities, and a wide range of natural and cultural tourist attractions, e.g. landscape, monuments, atmosphere, which attract tourists to the chosen place $(\mathrm{Bu}-$ halis, 2000; Crouch, 2011; Leiper, 1990; Richards, 2002; UNWTO, 2007).

Bornhorst, Ritchie \& Sheehan (2010) stress that a tourism destination has two primary roles to fulfill. First and foremost, it must seek to ensure the social and economic well-being of the local community which lives within its boundaries. Secondly, to be considered as a tourist destination, it must offer a wide range of products and services to fulfill tourists' needs.

The reference to tourism needs, leads to another definition which is currently shared by most of researchers. A tourism destination is perceived as "a collection of experiences" acquired by travelers, where visitors numbers dynamically activate the supply network (Barnes, Mattsson, Sørensen, 2014; Gunn, 1972; Keller, 2000; Ritchie, Hudson, 2009). As a result of this tourism suppliers benefit from visitors by establishing a supply chain (Beritelli, 2011a; Pearce, 2014).

Yet, due to globalization pressures substitution especially among nature-based tourism destinations is becoming pervasive (Dwyer, Edwards, Mistilis, Roman, Scott, 2009). Thus, every host area should be better positioned and differentiate its products through a dynamic and innovative value chain in order to gain a competitive advantage (Gursoy Saayman, Sotiriadis, 2015; Fine, 2000; Klimek, Doctor, 2018; Vengesayi, 2003). Nevertheless, as stated by Padurean (2010), Laesser \& Beritelli (2013) and other authors throughout the literature, mountain destinations are nowadays multifaceted. Their supply chain is often fragmented among several interest groups (Beritelli, 2011b). Since nature-based areas have become extremely dynamic and complex entities, topdown traditional approaches commonly used by the public sector have not always been consistent for different and often conflicting goals inside the destinations (Beriteli, Leasser, 2011; Byrd, 2007; Lai, Hsu, Wearing,
2016; Pechlaner, Tschurtschenthaler, 2003; Sheehan, Ritchie, 2005). Thus, already since the 1960s, Swiss and other Alpine destinations have evolved from a marketing and product-based focus to a more collaborative approach based on bottom-up, less bureaucratic and decentralized forms of destination governance, i.e. through destination management organizations (Bieger, 1998; Beritelli, Bieger, Laesser, 2007). The Destination Management Organization (DMO) is a model of governance based on a public-private partnership which refers to a coalition of many tourist organizations working together towards mutual goals (Elbe, Hallén, Axelsson, 2009; UNWTO, 2007). DMOs are mostly non-profit publicprivate organizations. Their main functions include strategic management of a destination, shaping its cohesive marketing and branding strategy, information and tourism activities, cooperation with local interest groups and lobbying in order to create and commercialize tourism products as well as protecting the interests of local communities (Gertzel, 2006; Presenza, Sheehan, Ritchie, 2005). Switzerland has become one of the first countries where DMOs were implemented on a local as well as regional level within the framework of the publicprivate partnership (Klimek, 2014). Apart from Switzerland, DMOs also function successfully in several European regions and throughout the world.

However, in many mountain destinations perceptions of holistic destination governance are still divergent among stakeholder groups (Benčič, 2006; Baggio, Scott, Cooper, 2010). Poland is a country with relatively poor solutions developed in the area of complex tourism management on all local, regional and nationwide levels (Fedyk, Meyer, Potocki, 2017). In spite of the fact that it is an increasingly common belief that the DMO model should be implemented to manage tourism destination areas, local and regional tourist organizations operating still do not possess such competences and qualifications (Borzyszkowski, 2013; Czernek, 2012; Klimek, 2013). This is also the case in the Bieszczady mountains.

According to Szulc-Dąbrowiecka \& Żuławska (2015), there are two principal stages of tourism management in this area. The first phase was between 1952 and 1989 when the state played the dominant role in the management of tourism (the top-down approach). The second stage (from 1990 to the present) has been when regional governance has been handed over to different publicprivate entities and organizations. Hence, their roles and competences often overlap having an impact on the direction and effectiveness of their actions. Thus, despite many strategic documents elaborated for the development of this region in a bottom-up approach, there is still lack of the holistic management of tourist numbers in the Bieszczady moutains.

Masses of tourists coming each year to the most attractive zones, such as the Solina region or the Bieszczadz- 
ki National Park, cause many social and environmental problems (Myga-Piątek, Jankowski, 2009; Świgost, 2017; Wolski, 2007). At the same time, as tourists numbers in the Bieszczady mountains are mostly concentrated in the areas of their biggest attractions, many natural and cultural attractions situated in neighboring communes are not visited (e.g. the amenities of Lesko, Baligród or Ustrzyki Dolne). Moreover, tourist arrivals to the Bieszczady mountains are strongly seasonal and concentrated mainly in the summer (US, 2018). Therefore, this region needs examples of best practices from other destinations which have already introduced new standards based on a holistic concept of destination management. Hence, the idea to implement a new approach to holistic destination management based on the St. Gallen Model for Destination Management, SGDM in this area (Beritelli, Reinhold, Laesser, Bieger, 2015).

The SGDM model offers a demand-driven, realistic perspective for the development of tourist destinations and is based on the following main assumptions:

1. Tourism destination is shaped and defined by tourists.

2. The majority of tourists who arrive at a chosen reception area seek to satisfy similar needs, so they behave in a similar way and activate similar supply elements. Hence, the demand activates the supply chain and not vice versa.

3. Strategic visitor flows (SVFs) are the basic units for the strategic planning and holistic management of the destination.

4. The reconstruction of the way in which strategic segments (of SVFs) arrive at the destination permits better management of tourist numbers and a more adequate development of the destination offers which are adapted to satisfy real tourist needs.

5. The SGDM model is not based on quantitative data on tourist numbers, which are very often fragmented and not comparable, but it relies on the knowledge and service experience of public and private destination actors. Hence, the key local stakeholders, i.e. tourism entrepreneurs, informal interest groups, non-governmental organizations, tourism associations, and public entities - local authorities etc - play an essential role in the identification of SVFs and the successful implementation of the whole method.

6. Strategic planning and the division of tasks in this model are performed for each SVF and not for the entire destination in an ad hoc manner, which allows the optimization of marketing and promotion costs and better resource management thanks to more effective process management.

This market-driven and network-oriented approach has been created by Swiss academics from St. Gallen University and is built on their practical experience in more than forty destinations worldwide. In autumn 2018 this approach was implemented ${ }^{1}$ in six Bieszczady communes, i.e. Baligród, Cisna, Lesko, Olszanica, Solina and Ustrzyki Dolne. ${ }^{2}$

\section{METHODOLOGY AND RESEARCH QUESTIONS}

The SGDM model which was applied in the six Bieszczady communes is a circular, bottom-up, six-step approach, which comprises the following activities:

- identification of the strategic visitor flows (SVFs) and their graphic visualization on destination maps,

- overlaying of the individual SVF and assessment of the SVF portfolio for each commune,

- analysis and reconstruction of the supply and demand network in each destination regarding the SVFs indicated,

- assessment of existing marketing activities per SVF and planning new strategic actions for existing and new ones,

- appraisal of SVFs and a constant updating of marketing and management activities by a sustainable use of resources and the common decision-making process of key stakeholders.

Moving from one stage to another is a process that allows key local stakeholders to comprehensively manage destinations through identification, planning activities and managment of strategic visitor flows (see. Figure 1).

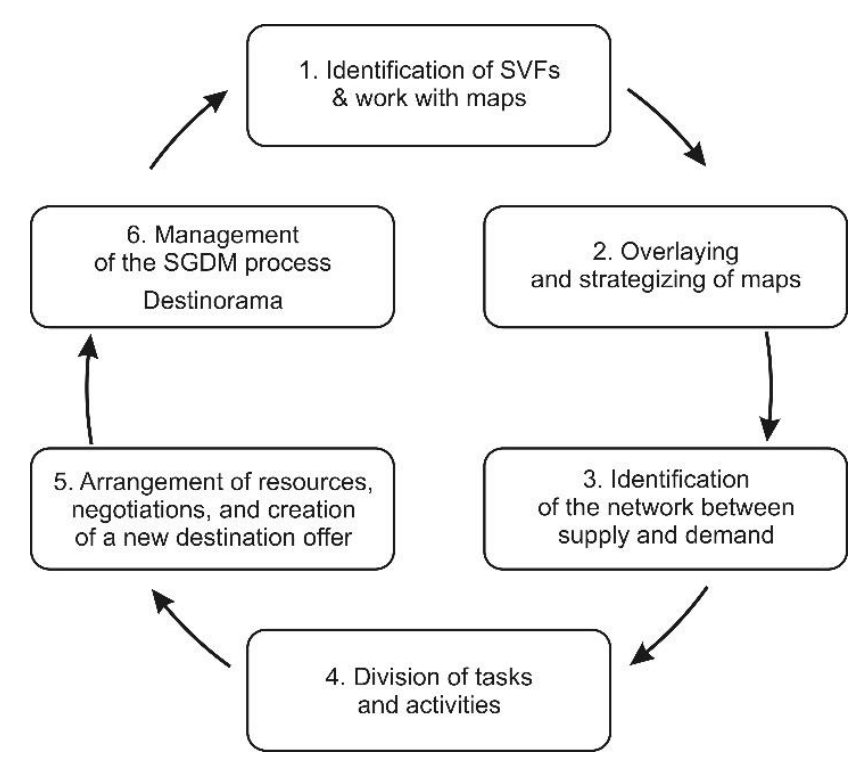

Figure 1. The SGDM model implemented in selected Bieszczady communes Source: author based on: Beritelli, Reinhold, Leasser, Bieger (2015) 
The identification of SVFs for each commune and the challenges related to their management took place during working meetings organised with key local stakeholders.

Taking into consideration all those challenging aspects of the SGDM model, and the issues stated in literature, the aim of the implementation of this approach in the Bieszczady region was to find the answers to the following research questions:

1. What strategic visitor flows (SVFs) can be identified in selected Bieszczady communes (SVF) and how they are developed (in terms of the number of visitors)? What kind of SVF can be developed in the future?

2. What are the supply-demand relationships and what kind of stakeholders are involved in tourism development in chosen destinations?

3. What are the main problems in the management of the existing SVFs and possible solutions to boost inter- and supra-communal cooperation and tourism product development?

4. Is the concept of the SGDM an effective tool to boost inter- and supra-communal cooperation in order to enhance the long-term tourism development of the six chosen communes?

\section{DESCRIPTION OF THE RESEARCH SAMPLE AND THE PROCESS OF SGDM MODEL IMPLEMENTATION}

The implementation required many months of preparation, above all related to the selection of key stakeholders and the preparation of materials (maps) constituting the basic element of meetings.

The choice of the research sample (public and private) was carried out on the basis of strictly determined criteria, i.e.

- the selected subjects at present play a key role in the development of tourism in particular communes as well as in the creation of their tourist product;

- there is a network of interconnections between them, although at present the degrees and ranges of cooperation vary, nevertheless, tourism constitutes an important sector of their economies and a source of income. ${ }^{3}$

Five groups of key stakeholders were chosen within the selection process:

1. Tourism service providers: representatives of accommodation, catering facilities and the tourism attractions sector.

2. Local organizers of tourism: travel agencies, tourist guides.
3. Forestry (State Forests).

4. Representatives of local authorities (commune, district).

5. Local Action Groups/associations/NGO representatives.

The meetings with the stakeholders, divided by sector, took place in Orelec and Ustrzyki Dolne in November and December 2018. Approximately 50 representatives of various sectors from the six communes took part in those meetings. ${ }^{4}$

In order to define and differentiate the strategic visitor flows (SVF) from other groups of visitors, at the beginning of each meeting the participants were provided with a description of the characteristic features for each strategic visitor flow.

Each SVF:

- is composed of a large number of tourists;

- is relatively stable and foreseeble in time;

- can be located on 2-3 types of map;

- has its own supply and demand mechanism;

- has its own dynamic and life cycle and has an opportunity to generate revenue;

- can be stimulated by supply, as well as analyzed, managed and commercialized.

Afterwards, the stakeholders marked numbers on the maps which had been prepared beforehand. Depending on the size of the commune, these were printed at two or three scales for each of the communes (see Figure 1, point 1). At the initial stage of work with the maps, the commune representatives selected the most suitable for a given SVF. Next, they drew the routes which tourists from each strategic flow take when they arrive in a given commune (see Figure 2, point 2), and they highlighted all the attractions and supply elements which are activated by SVF during a tourism visit (see Figure 1, point 3). Every SVF was marked and described separately on one type of map.

Apart from graphically situating all strategic visitor numbers (SVFs) on the maps, another important element was to precisely describe SVFs through completing the key under each map (see Figure 2 point 4 ).

The key consists of several fields that allow each SVF to be described in detail. Stakeholders characterize a key segment by finding answers to the following questions for every SVF:

- Who are our guests (SVFs)? What name can be given to the segment?

- Are they day or overnight visitors (D/N)?

- Where do the visitors forming the SVF come from? Where do they go and what do they do during their stay? What do they purchase and how much do they spend?

- Why do the tourists come to the destination?

- When do they come?

- What is the phase in the SVF life cycle? 


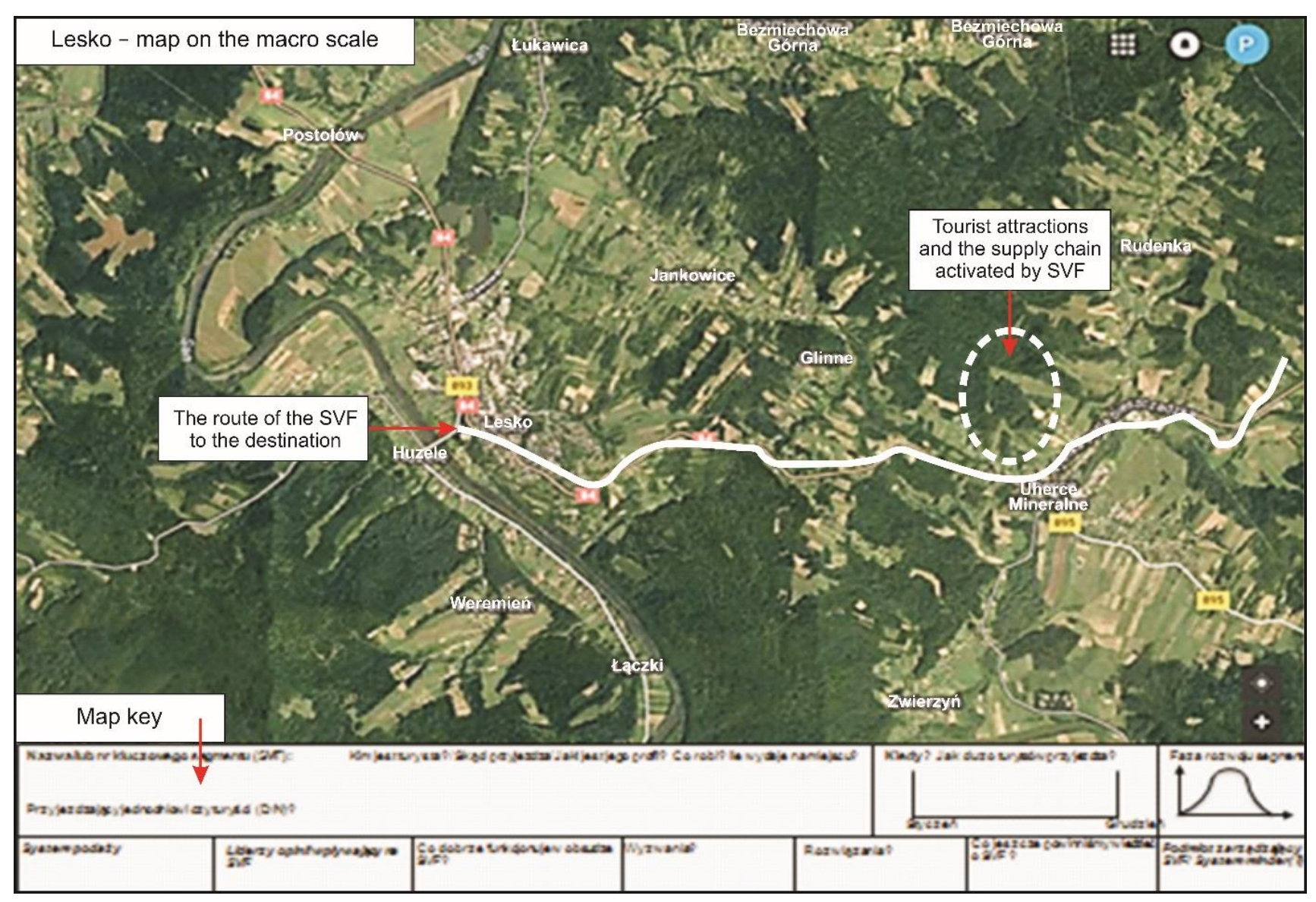

Figure 2. Example of the Lesko map at a macro scale Source: author based on: Beritelli, Reinhold, Laesser, Bieger (2015)

The lower part of the key served the purpose of defining the key elements of the supply (system head(s)) and which opinion leaders (market mavens) exert an impact on each analyzed SVF.

The applied method also permitted functions to be determined in the service of the described segment, and what needs to be improved. Possible solutions constituted the basis for discussion between the stakeholders in order to plan specific activities intended to better adjust supply to the needs of the SVF. The discussion results and proposed activities are included in the following item related to the presentation of results.

\section{THE RESEARCH RESULTS}

The conducted meetings resulted in the completion of 52 maps and the identification of 32 existing SVFs in six Bieszczady communes as well as three potential segments whose development is planned in the future (see Table 1). After the overlaying of the maps and elimination of repetition, the work from the first meetings was presented to the stakeholders in the form of a so-called destinorama (an exhibition created from all printed maps) during the summarizing meeting which took place in December 2018 in Ustrzyki Dolne.

Table 1. Presentation of completed maps and identified key SVFs

\begin{tabular}{|l|c|c|}
\hline $\begin{array}{c}\text { Name of the } \\
\text { commune }\end{array}$ & $\begin{array}{c}\text { Number } \\
\text { of completed } \\
\text { maps }\end{array}$ & $\begin{array}{c}\text { Number of identified } \\
\text { strategic segments }\end{array}$ \\
\hline Baligród & 6 & $4+3$ potential \\
\hline Cisna & 10 & 7 \\
\hline Olszanica & 5 & 2 \\
\hline Lesko & 18 & 7 \\
\hline Solina & 6 & 7 \\
\hline $\begin{array}{l}\text { Ustrzyki } \\
\text { Dolne }\end{array}$ & 7 & $4+1$ potential \\
\hline Together & 52 & 34 \\
\hline
\end{tabular}

Source: author on the basis of the meetings.

Below is a table of the characteristics of the SVFs in the six Bieszczady communes (see Table 2). 
Table 2. Kinds and characteristics of the most important strategic visitors flows identified by the stakeholders in six Bieszczady communes

\begin{tabular}{|c|c|c|c|c|c|}
\hline Kind of segment & Name of SVF & $\begin{array}{l}\text { Name } \\
\text { of the commune }\end{array}$ & Characteristics of the strategic segment & $\begin{array}{l}\text { One-day } \\
\text { visitors }\end{array}$ & Tourists \\
\hline \multirow{14}{*}{ Existing SVFs } & Nature lovers & Baligród, Cisna & $\begin{array}{l}\text { Nature lovers, enthusiasts, families with } \\
\text { children from all over Poland, physically ac- } \\
\text { tive young people }\end{array}$ & & $x$ \\
\hline & $\begin{array}{l}\text { Families } \\
\text { with children }\end{array}$ & $\begin{array}{l}\text { Baligród, Cisna, } \\
\text { Lesko, Solina, }\end{array}$ & $\begin{array}{l}\text { Families with children of different ages, } \\
\text { travelling by car (from all over Poland). In } \\
\text { the communes of Baligród, Cisna and Lesko } \\
\text { these are mainly transit tourists, and in the } \\
\text { communes of Cisna and Solina these are } \\
\text { tourists staying in guest houses from } 3 \text { days } \\
\text { up to one week. }\end{array}$ & $x$ & $x$ \\
\hline & $\begin{array}{l}\text { Groups of friends } \\
\text { and students }\end{array}$ & Baligród, Cisna & $\begin{array}{l}\text { Students from higher education institu- } \\
\text { tions (Kraków, Lublin, Rzeszów), couples or } \\
\text { families }\end{array}$ & $\mathrm{x}$ & $x$ \\
\hline & School groups & $\begin{array}{l}\text { Solina, Cisna, } \\
\text { Ustrzyki Dolne }\end{array}$ & $\begin{array}{l}\text { Pupils coming for residential school trips or } \\
\text { other organized stays. They stay at the So- } \\
\text { lina lake for a few days during the spring or } \\
\text { summer }\end{array}$ & $x$ & \\
\hline & $\begin{array}{l}\text { Transit and sight- } \\
\text { seeing tourists }\end{array}$ & $\begin{array}{l}\text { Baligród, Cisna, } \\
\text { Lesko }\end{array}$ & $\begin{array}{l}\text { Tourists arriving by car from all over Po- } \\
\text { land and abroad. Organized trips, seniors, } \\
\text { juniors (school groups visiting attractions } \\
\text { on the way to the Solina lake). }\end{array}$ & $\mathrm{x}$ & \\
\hline & $\begin{array}{l}\text { DINKS - Double } \\
\text { Income no Kids }\end{array}$ & Cisna & $\begin{array}{l}\text { Childless couples (older marriages), } 80 \% \text { from } \\
\text { Warsaw, } 20 \% \text { from Lower Silesia and Pom- } \\
\text { erania. Stays from } 3 \text { to } 7 \text { days. }\end{array}$ & $\mathrm{x}$ & \\
\hline & 'Lone travelers' & Cisna, Lesko & $\begin{array}{l}\text { Individual tourists, mainly men in work } \\
\text { from all over Poland, } 40 \text { or more years old. } \\
\text { These are mainly weekend tourists (Cisna) } \\
\text { or one-day tourists (Lesko). }\end{array}$ & $\mathrm{x}$ & $x$ \\
\hline & $\begin{array}{l}\text { Participants in cor- } \\
\text { porate team build- } \\
\text { ing trips and in } \\
\text { company-organized } \\
\text { trips for employees }\end{array}$ & Cina, Solina & $\begin{array}{l}\text { Employees (30-60 years old) from Mało- } \\
\text { polska (Kraków), the Mazovia region (War- } \\
\text { saw) and the Lublin region. Most frequently } \\
\text { 3-day stays. }\end{array}$ & & $x$ \\
\hline & $\begin{array}{l}\text { Participants in the } \\
\text { 'Bieg rzeźnika' } \\
\text { ultramarathon event }\end{array}$ & Cisna & $\begin{array}{l}\text { Sports people with families from all over Po- } \\
\text { land and abroad. They stay overnight at the } \\
\text { Cisna communal tourism base for between } \\
2 \text { and } 7 \text { days, before during and after the } \\
\text { event. }\end{array}$ & & $x$ \\
\hline & $\begin{array}{l}\text { 'Edu-tourists' and } \\
\text { cultural tourists }\end{array}$ & $\begin{array}{l}\text { Olszanica, Ustrzyki } \\
\text { Dolne }\end{array}$ & $\begin{array}{l}\text { Individual tourists, organized groups from } \\
\text { all over Poland and abroad, families with } \\
\text { children and multi-generation families, youth } \\
\text { groups, cyclists, bikers, groups of friends, } \\
\text { one-day and longer stays. They visit 'bicycle } \\
\text { trolleys', the Bieszczady School of Craft } \\
\text { and the Ursa Maior brewery, the Eco-mu- } \\
\text { seum, the palace in Olszanica, the Museum } \\
\text { of the Rural Life and Agriculture. }\end{array}$ & $x$ & $x$ \\
\hline & Skiers & Lesko & Local skiers, families with children & $x$ & \\
\hline & $\begin{array}{l}\text { International fishing } \\
\text { groups }\end{array}$ & Lesko & $\begin{array}{l}\text { Anglers (from all over Poland and abroad), } \\
\text { all of Europe but mainly Italians, French and } \\
\text { Czech. This is a segment of rich tourists. They } \\
\text { stay in Lesko at least } 3 \text { days, spend from } \\
200 \text { PLN to } 500 \text { PLN per person per day. }\end{array}$ & & $x$ \\
\hline & $\begin{array}{c}\text { 'Water sports } \\
\text { lovers': river rafting } \\
\end{array}$ & Lesko & $\begin{array}{l}\text { Groups, adults and schools from all over } \\
\text { Poland }\end{array}$ & $x$ & \\
\hline & Sailors & Solina & $\begin{array}{l}\text { Local sailors from all over Poland, youth, } \\
\text { students, parents with children. Visits last- } \\
\text { ing a few days during the summer. }\end{array}$ & & $x$ \\
\hline
\end{tabular}




\begin{tabular}{|c|c|c|c|c|c|}
\hline Kind of segment & Name of SVF & $\begin{array}{l}\text { Name } \\
\text { of the commune }\end{array}$ & Characteristics of the strategic segment & $\begin{array}{l}\text { One-day } \\
\text { visitors }\end{array}$ & Tourists \\
\hline \multirow{5}{*}{ Existing SVFs } & $\begin{array}{l}\text { Gliders and para- } \\
\text { gliders }\end{array}$ & Lesko & $\begin{array}{l}\text { Active tourists, sports people, tourists who } \\
\text { would like to enjoy scenic flights. These are } \\
\text { one-day tourists and guests staying for train- } \\
\text { ing for a few days. }\end{array}$ & $x$ & $x$ \\
\hline & $\begin{array}{l}\text { Runners } \\
\text { and swimrunners }\end{array}$ & Solina & $\begin{array}{l}\text { Sports people from Poland and all over Eu- } \\
\text { rope. Tourists spending approximately one } \\
\text { week on their sports at the Solina lake }\end{array}$ & & $x$ \\
\hline & $\begin{array}{l}\text { Health resort } \\
\text { patients }\end{array}$ & Solina & $\begin{array}{l}\text { Health resort patients coming throughout } \\
\text { the year for the sanatorium treatment to Po- } \\
\text { lańczyk Zdrój from Małopolska, Silesia, } \\
\text { Mazovian and Lublin regions }\end{array}$ & & $x$ \\
\hline & Pilgrims & Ustrzyki Dolne & $\begin{array}{l}\text { Adults from the Subcarpathian region visit- } \\
\text { ing shrines }\end{array}$ & & $x$ \\
\hline & Seniors & Ustrzyki Dolne & $\begin{array}{l}\text { Enthusiasts of travelling and hiking, enjoy- } \\
\text { ing natural attractions }\end{array}$ & & $x$ \\
\hline \multirow{2}{*}{ Potential segments } & $\begin{array}{c}\text { Herbalism } \\
\text { and pastoralism }\end{array}$ & Baligród & $\begin{array}{l}\text { Pupils from primary and secondary schools, } \\
\text { families with children }\end{array}$ & $x$ & \\
\hline & $\begin{array}{l}\text { Cultural tourist } \\
\text { and pilgrims }\end{array}$ & $\begin{array}{l}\text { Baligród, Ustrzyki } \\
\text { Dolne }\end{array}$ & Enthusiasts of orthodox art and pilgrims & $x$ & \\
\hline
\end{tabular}

Source: author on the basis of research results.

As a result of discussions taking place during the meetings while working with the maps, the most important problems and challenges in the area of SVF management were identified. This contributed towards the elaboration of proposed solutions which would engage both public and private stakeholders. The main problems and proposals are presented in Table 3.

The SGDM approach and the results of a post-meeting questionnaire ${ }^{5}$ allowed a better understanding of the current situation regarding the level of cooperation between key public and private stakeholders and to determine their role in SVF management (see Figure 3).

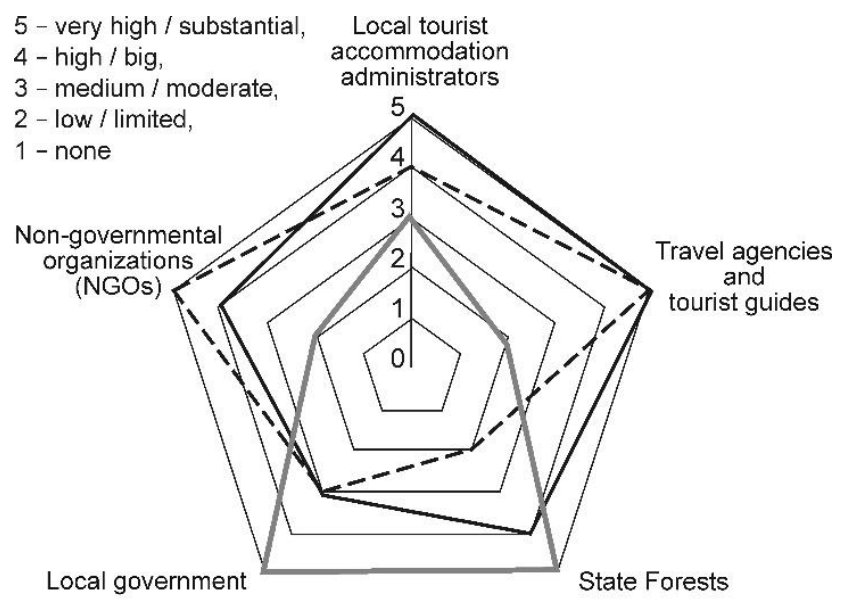

Innovation budget, tourism marketing

- - - Willingness to cooperate with public and private partners

Role in SVFs (Strategic Visitor Flows) management

Figure 3. Level of cooperation and the role of the research sample in SVF management

Source: author based on the SGDM approach and the survey results
One of the key results of the implemented method consisted of enabling local stakeholders to see in which places of the supply chain there was a lack of effective cooperation. An analysis of the supply allows the basic characteristics of a system head in the supply network to be seen. The characteristics of key stakeholders are:

- Local tourism service providers seem to have the greatest willingness to cooperate to boost tourism in selected communes. Their activities and the spirit of innovation are crucial to attract new tourism segments to the area. However, they are mostly small entrepreneurs with limited sources of financing.

- Contrary to tourist guides, local travel agencies are entities which are very open to wide public and private cooperation.

- As forest areas constitute over $60 \%$ of the whole territory of the Bieszczady region, forestry remains a very important public stakeholder in tourism development. Working alone, forestry enters more frequently into cooperation with local governments than with private partners. But, as this entity disposes of large funds for development, it is actively involved in the creation of new tourist attractions or accommodation facilities, also maintaining tourist routes and other infrastructure on forestry territory.

- Due to financial resources, local governments play a very important role in boosting tourism in the selected area. Yet, they often have a different vision of tourism development than private interests. Moreover, they are often small communes and have inadequate human resources to manage local tourism. 
- NGOs are close to the local community, very active in initiating various types of projects, tourist products and local attractions (e.g. eco-museum). But they are often faced with human and financial resource problems.

Moreover, the stakeholders recognised the necessity for common activities enhancing the market in order to, on the one side, intensify the arrivals of tourists from key SVFs and, on the other, promote natural and cultural attractions which, in spite of their tourism significance, are frequently not visited by tourists.

This issue seems to be of particular importance in the context of the dynamically developing mass tourism in the Solina commune. On account of the diverse tourism offer, this region attracts mass tourists especially in the period between May and November as well as, in the case of Polańczyk Zdrój, health resort patients for sanatorium treatment throughout the year. Nevertheless, the concentration of SVFs mainly in the area of this commune results in great transportation difficulties in the high season for both tourists and the local community.

Therefore, the promotion of new attractions in neighbouring communes seems of key importance in order to better maage tourism in this region. The recently created tourist attractions in the Olszanica commune (i.e. 'draisine bikes', the Eco-museum, the Bieszczady School of Craft and the Ursa Maior brewery) ${ }^{6}$ may constitute a positive example of cooperation between the local government and local entrepreneurs in this respect. Due to the proximity of the Bieszczadzki National Park, the Cisna and Ustrzyki Dolne communes also try to attract tourists and convince them to stay by creating offers from 3 to 7 days.

Table 3. Main challenges for communes in the area of SVF management as well as solutions to the problems proposed by key stakeholders

\begin{tabular}{|c|c|c|}
\hline $\begin{array}{l}\text { Name of commune } \\
\text { and characteristics of tourism }\end{array}$ & Problem/challenge & Solutions proposed by stakeholders \\
\hline \multirow{4}{*}{$\begin{array}{l}\text { Baligród commune } \\
\text { The majority of tourists in this com- } \\
\text { mune are one-day tourists coming } \\
\text { mainly from May to September, av- } \\
\text { erage spending of } 100-200 \text { PLN per } \\
\text { person, all SVFs in the growth phase. }\end{array}$} & $\begin{array}{l}\text { - Difficulties related to transportation } \\
\text { availability in the commune. At pres- } \\
\text { ent the commune is accessible mainly for } \\
\text { tourists arriving by car. However, the } \\
\text { offer addressed to visitors preferring } \\
\text { public means of transportation is very } \\
\text { limited. }\end{array}$ & $\begin{array}{l}\text { - Creating a system of incentives in the com- } \\
\text { mune for people who would like to invest } \\
\text { in group passenger transportation services. }\end{array}$ \\
\hline & $\begin{array}{l}\text { - The networks of catering and accom- } \\
\text { modation facilities as well as attrac- } \\
\text { tions for children (playgrounds, play- } \\
\text { ing fields, places for active spending of } \\
\text { time) are poorly developed. }\end{array}$ & $\begin{array}{l}\text { - Intensifying the cooperation between the com- } \\
\text { mune local government and the local commu- } \\
\text { nity as well as entrepreneurs in order to ex- } \\
\text { pand the accommodation-catering offer (e.g. } \\
\text { campsites and attractions for children). } \\
\text { - Creating a system of incentives for new in- } \\
\text { vestors. }\end{array}$ \\
\hline & $\begin{array}{l}\text { - Poorly signposted attractions and the } \\
\text { tourism offer in the commune. }\end{array}$ & $\begin{array}{l}\text { - Introducing a unified system of marking } \\
\text { tourist attractions as well as accommoda- } \\
\text { tion and catering facilities in order to per- } \\
\text { suade transit tourists to stay and increase } \\
\text { tourism in the commune. }\end{array}$ \\
\hline & $\begin{array}{l}\text { - The short length and low number of } \\
\text { cycling routes. }\end{array}$ & $\begin{array}{l}\text { - Extending the cycling routes and connect- } \\
\text { ing them to routes in Cisna commune is, } \\
\text { according to stakeholders, of key impor- } \\
\text { tance in order to attract cyclists. To achieve } \\
\text { that aim, it is necessary to develop a com- } \\
\text { mon project for cycling routes and inten- } \\
\text { sify the cooperation between the Baligród } \\
\text { and Cisna communes. }\end{array}$ \\
\hline $\begin{array}{l}\text { Cisna commune } \\
\text { The majority of tourists in this com- } \\
\text { mune stay in the commune for } 3 \text { days } \\
\text { or longer, mainly from March to } \\
\text { October. } \\
\text { All SVFs are in the growth phase. }\end{array}$ & $\begin{array}{l}\text { - Lack of mountain hostels (accommo- } \\
\text { dation facilities along mountain trails). } \\
\text { - Lack of local transportation systems. } \\
\text { - Too few car parking spaces and cycling } \\
\text { routes. } \\
\text { - Poor transport accessibility of villages. }\end{array}$ & $\begin{array}{l}\text { - Intensifying activities and cooperation be- } \\
\text { tween the local government, enterprises } \\
\text { and associations in order to build 2-3 new } \\
\text { moun-tain hostels as well as a system of in- } \\
\text { centives for the creation of a seasonal trans- } \\
\text { portation offer by private entrepreneurs } \\
\text { would decisively ex-tend the length of tour- } \\
\text { ists' stay. } \\
\text { - Strengthening the public-private partner- } \\
\text { ship in the area of the commune was pro- } \\
\text { posed in order to achieve this aim. }\end{array}$ \\
\hline
\end{tabular}




\begin{tabular}{|c|c|c|}
\hline $\begin{array}{c}\text { Name of commune } \\
\text { and characteristics of tourism }\end{array}$ & Problem/challenge & Solutions proposed by stakeholders \\
\hline & $\begin{array}{l}\text { - Too limited an offer for children, with } \\
\text { respect to both the infrastructure and } \\
\text { the activity program addressed to the } \\
\text { youngest. }\end{array}$ & $\begin{array}{l}\text { - Creating an activity program for children } \\
\text { in the summer season (both paid and free } \\
\text { attractions) as well as extending the infra- } \\
\text { structure in this area. }\end{array}$ \\
\hline \multirow{3}{*}{$\begin{array}{l}\text { Olszanica commune } \\
\text { The SVFs in the Olszanica com- } \\
\text { mune include both tourists staying } \\
\text { overnight and one-day tourists. The } \\
\text { tourists spend on average between } \\
350 \text { PLN and } 400 \text { PLN. } \\
\text { All segments are in the dynamic } \\
\text { growth phase, mainly from April to } \\
\text { November }\end{array}$} & $\begin{array}{l}\text { - Absence of new investors in the tour- } \\
\text { ism industry. }\end{array}$ & $\begin{array}{l}\text { - Creation by local government of a system } \\
\text { of incentives for new investors is neces- } \\
\text { sary. }\end{array}$ \\
\hline & $\begin{array}{l}\text { - Lack of an exclusive offer for well-to- } \\
\text { do families and tourists who arrive in } \\
\text { bigger and bigger numbers in the Ol- } \\
\text { szanica commune. }\end{array}$ & $\begin{array}{l}\text { - Developing a new product offer which } \\
\text { would allow an extension of stays in the } \\
\text { commune, e.g. by organizing cyclical events } \\
\text { and concerts, diversifying prices and pre- } \\
\text { paring good advertising. }\end{array}$ \\
\hline & $\begin{array}{l}\text { - Creation of additional attractions in or- } \\
\text { der to encourage tourists stay longer. }\end{array}$ & $\begin{array}{l}\text { - Introducing markings on all tourist trails } \\
\text { and improving waterfall management. } \\
\text { - Intensifying cooperation between local } \\
\text { guides, guest houses owners and local gov- } \\
\text { ernment. } \\
\text { - Launching a new advertizing campaingn } \\
\text { in the social media, financed from public- } \\
\text { private resources. }\end{array}$ \\
\hline \multirow{6}{*}{$\begin{array}{l}\text { Lesko commune } \\
\text { The majority of tourists in this com- } \\
\text { mune are one-day and transit tourists. } \\
\text { The tourists include anglers and glid- } \\
\text { ers, whereas one-day trippers are or- } \\
\text { ganized groups and skiers. School } \\
\text { groups are in a declining phase, the } \\
\text { remaining SVFs are in growth and } \\
\text { maturity phases. Spending averages } \\
\text { from } 40 \text { PLN to a several hundred } \\
\text { PLN per person per day. }\end{array}$} & $\begin{array}{l}\text { - The skiers segment is in the initial } \\
\text { phase of development. }\end{array}$ & $\begin{array}{l}\text { - Expanding the skiing infrastructure in or- } \\
\text { der to attract a higher number of skiers from } \\
\text { out-side of the commune. }\end{array}$ \\
\hline & $\begin{array}{l}\text { - Too short stays (most frequently one- } \\
\text { day) of organized groups and school } \\
\text { groups in Lesko and the commune. } \\
\text { - There is a stereotype that Lesko is a tran- } \\
\text { sit town on the way to the Bieszczady } \\
\text { mountains and Solina lake. }\end{array}$ & $\begin{array}{l}\text { - Building parking spaces for coaches in the } \\
\text { centre of the town. } \\
\text { - Creating interesting attractions for children, } \\
\text { modernizing the infrastructure, offering } \\
\text { a modern approach to organized groups } \\
\text { and offering them a better service. } \\
\text { - Improving cooperation between the lo- } \\
\text { cal government, local entrepreneurs and } \\
\text { local guides is necessary to achieve this } \\
\text { aim. }\end{array}$ \\
\hline & $\begin{array}{l}\text { - Apart from the swimming pool, there } \\
\text { are few options which could be offered } \\
\text { for individual tourists and groups dur- } \\
\text { ing a period of bad weather. }\end{array}$ & \multirow{2}{*}{$\begin{array}{l}\text { - Developing a system of offers which would } \\
\text { permit the combination of tourist attrac- } \\
\text { tions and additional services (e.g. catering), } \\
\text { which would make it possible to spend } \\
\text { time in an interesting way in the Lesko } \\
\text { commune, regardless of weather condi- } \\
\text { tions and season. }\end{array}$} \\
\hline & $\begin{array}{l}\text { - Poor accessibility of attractions and } \\
\text { their poor promotion, leads to the } \\
\text { fact that tourists are not aware of } \\
\text { the existence of attractions of unique } \\
\text { cultural and natural features, and do } \\
\text { not visit them. }\end{array}$ & \\
\hline & $\begin{array}{l}\text { - Poor quality services offered to foreign } \\
\text { tourists, such as anglers and gliders. }\end{array}$ & $\begin{array}{l}\text { - It is necessary to organize language courses } \\
\text { for the personnel directly engaged in the } \\
\text { service of this SVF in the area of the com- } \\
\text { mune. } \\
\text { - Creating special offers for international } \\
\text { groups of anglers, paragliders and gliders, } \\
\text { who stay in the commune area for at least } \\
3 \text { days and generate high revenues, in or- } \\
\text { der to persuade them to see the attractions } \\
\text { which most frequently are never visited by } \\
\text { them during their stay. }\end{array}$ \\
\hline & $\begin{array}{l}\text { - River rafting is gaining more and } \\
\text { more popularity among groups of } \\
\text { tourists, but there are no river havens } \\
\text { and, in addition, there is a problem } \\
\text { with unstable water levels in the San } \\
\text { river. }\end{array}$ & $\begin{array}{l}\text { - Building river havens, more effective pro- } \\
\text { moting of water attractions. } \\
\text { - Improving the safety level for tourists tak- } \\
\text { ing advantage of river rafting. }\end{array}$ \\
\hline
\end{tabular}


Table 3 (cont.)

\begin{tabular}{|c|c|c|}
\hline $\begin{array}{l}\text { Name of commune } \\
\text { and characteristics of tourism }\end{array}$ & Problem/challenge & Solutions proposed by stakeholders \\
\hline $\begin{array}{l}\text { Solina commune } \\
\text { On account of the picturesque lake, } \\
\text { the Solina commune attracts the most } \\
\text { tourists of all the six communes. These } \\
\text { are tourists who stay from } 3 \text { days to } \\
\text { a week, and even longer. The vari- } \\
\text { ety of segments and the length of } \\
\text { their stays result in the fact that tour- } \\
\text { ism is considerably expanded in com- } \\
\text { parison with the other communes } \\
\text { (owing to sanatorium patients, tour- } \\
\text { ism in Polanczyk takes place through- } \\
\text { out the year). Tourists staying in the } \\
\text { area also spend more money than } \\
\text { tourists in the other communes, i.e. } \\
\text { from } 100 \text { PLN to several hundred PLN } \\
\text { per person per day. }\end{array}$ & $\begin{array}{l}\text { - Too few life-guarded swimming areas } \\
\text { and running routes. } \\
\text { - Problems related to security as well as } \\
\text { lack of attractions in case of unfavor- } \\
\text { able weather conditions. }\end{array}$ & $\begin{array}{l}\text { - Intensifying the public-private partnership } \\
\text { in order to: } \\
\text { - improve the safety of the swimmers and } \\
\text { sailors, } \\
\text { - create a higher number of life-guarded } \\
\text { swimming areas and havens which could } \\
\text { receive boats with tourists and dinghies, } \\
\text { - more secure swimming and running routes, } \\
\text { - create new attractions not dependent on } \\
\text { weather conditions, } \\
\text { - increase the number of local guides, who } \\
\text { would be able to persuade tourists to visit } \\
\text { the area. }\end{array}$ \\
\hline \multirow{3}{*}{$\begin{array}{l}\text { Ustrzyki Dolne commune } \\
\text { In the Ustrzyki commune the ma- } \\
\text { jority of tourists are overnight stay } \\
\text { tourists and groups, which is a pos- } \\
\text { itive indication as to the future de- } \\
\text { velopment of tourism in the region. }\end{array}$} & $\begin{array}{l}\text { - Convincing the tourist to stay longer } \\
\text { than } 3 \text { days, both in the summer and in } \\
\text { the winter. }\end{array}$ & $\begin{array}{l}\text { - Extending the ski lift infrastructure. } \\
\text { - Extending the offer of cultural events, fes- } \\
\text { tivals regarding Ustrzyki Dolne. }\end{array}$ \\
\hline & $\begin{array}{l}\text { - Extending the number of attractions, } \\
\text { SPA resorts, tourist paths and cycling } \\
\text { routes. }\end{array}$ & $\begin{array}{l}\text { - Expanding the infrastructure and creating } \\
\text { a border crossing permitting an increase } \\
\text { tourism in the commune area. } \\
\text { - Extending cycling routes and hiking trails. } \\
\text { - Creating a program of large events of na- } \\
\text { tionwide significance. } \\
\text { - Intensifying cooperation between local } \\
\text { government and local entrepreneurs is } \\
\text { necessary to achieve this aim. }\end{array}$ \\
\hline & $\begin{array}{l}\text { - Lack of an offer aiming to enhance } \\
\text { tourism out of season. }\end{array}$ & $\begin{array}{l}\text { - Attracting to the commune seniors and vis- } \\
\text { itors who do not have school age children } \\
\text { by creating for them special pre-season and } \\
\text { post-season packages. }\end{array}$ \\
\hline
\end{tabular}

Source: author on the basis of research results.

However, according to the map analysis, the Lesko and Baligród communes make the least use of their tourism potential. In spite of their transit location towards the Solina lake, their offer is by far the least attractive for tourists representing the key SVFs. The most important attractions are not signposted or promoted, which leads to the fact that tourists stop here only to take advantage of the catering offer or to go shopping. Therefore, in particular in these two communes, there arises the necessity to strengthen cooperation between local government and local entrepreneurs.

To summarize, it should be concluded that the implemented method has enabled the stakeholders to foster local and inter-communal cooperation. The discussions during working meetings inspired them to think beyond their borders, in order to plan collective actions which would permit them to maintain existing SVFs and to develop the new strategic segments.

\section{CONCLUSIONS}

The method of the St. Gallen Model for Destination Management applied in selected Bieszczady communes has made it possible to identify the strategic visitors numbers (SVFs) in all the six reception areas involved in the implementation of the model, allowing the first research question to be answered.

Moreover, with the help of the maps, the stakeholders specified which main elements of supply are activated by strategic segments of tourists, thus making it possible to identify these attractions and places which are of a particular value for tourists, and whose potential is still not fully utilized, (the second research question). It turns out that the majority of the places and attractions which are most frequently not visited by tourists are located in neighbouring communes on the way to Solina. This 
in particular refers to the Lesko and Baligród communes which function as transit places and in which tourists do not stop at all, or only for a very short time, e.g. in order to go shopping.

The completed map keys also made it possible to identify the main problems of particular communes with respect to the management of tourism as well as the division of competences and resources - the third research question.

It was pointed out that in the Baligród and Olszanica communes investors demonstrate no interest in the creation of new attractions or investment in the development of the tourism infrastructure. However, lack of financial resources for the development of tourism and tourism-related infrastructure does not seem to be the main problem of the communes which took part in the implementation of the SGDM model.

According to the stakeholders, the dominant challenge which is present in all the communes is, above all, the insufficient cooperation between local government, entrepreneurs and mountain guides as well as difficulties related to the division of competences and the coordination of activities between particular interests. A group of Bieszczady mountain guides who were present at the meetings also pointed out the lack of support for their services from both local government and local entrepreneurs, and in particular from tourist offices handling the arriving tourists or from points of tourist information.

It seems inter-communal cooperation is also rather limited, although it is of key importance for the creation of the common local tourist offer, e.g. for cyclists (cycling routes Baligród-Cisna) or skiers (integrated LeskoUstrzyki Dolne offer), as well as for foreign tourists (poor quality of service in foreign languages). In many communes there is a problem of the poor signposting of tourist attractions and trails which should be unified and not separately within every commune.

Apart from the all-year-round health resort developed in the Solina commune, the majority of the analyzed destinations do not possess an offer which would attract tourists throughout the year. The polarization of tourism is mainly from May to November. The intensified tourism in particular in the summer season leads to huge transportation problems on the roads leading towards particular communes as well as very long queues to particular attractions and catering facilities. These problems are intensified by the fact that access to particular communes is difficult and there is no integrated system of public transportation.

After the meetings, the stakeholders admitted in an anonymous post-meeting questionnaire that the implemented SGDM method has positively influenced the change of their perception of tourism as a system of connections between demand and supply.
Thanks to the method, their understanding of the necessity for cooperation has increased by making them aware that the long-term development of tourism is a common issue for them all (the fourth research question). This issue can be considered as being the greatest value of the implemented method. The Bieszczady case can be compared to many examples from other destinations described in "The St. Gallen Model for Destination Management (SGDM)" (Beritelli, Reinhold, Leasser, Bieger, 2015).

The identified problems and challenges in the area of SVF management which are faced by particular communes require one more step, i.e. planning and implementing the solutions which were prepared during the meetings, on both local and inter-communal levels. At present steps are being taken in order to obtain resources for the continuation of the implementation of the SGDM method in these communes.

The universal character of this model also makes it possible to implement the St. Gallen Model for Destination Management in other Polish tourism reception areas, especially in places where there are large disproportions in tourism intensity between particular destinations.

\section{ENDNOTES}

${ }^{1}$ The implementation of the method in Poland was possible thanks to the financial support of the Ministry of Sport and Tourism within the framework of the project entitled: "Innovative support tools for the territorial tourist brand of the Bieszczady Mountains".

2 There were a number of reasons why Lutowiska - one of the biggest communes located in the Solina region - was not included in the project. As the large commune area is protected and covered by the National Park, it results in a lack of sufficient key private tourism stakeholders. Moreover, the representatives of the National Park were not particularly open to dialogue and cooperation. The communal authorities seemed also to show limited interest and openness to the tourism development in this area.

3 The selection and invitation of stakeholders to the meetings were carried out by the personnel of the Pro Carpathia Association - a locally active entity which has been involved in the support of tourism in the Subcarpathian Region.

4 Prof. Pietro Beritelli from St. Gallen University, a co-author of the method, and the author of this article took part in its implementation in the Bieszczady mountains.

${ }^{5}$ The questionnaire consisted of four questions: 1 . What is the role of my company/organization in the management of current SVFs? 2. With what partners and on what scale my company/organization cooperates most willingly for the development of the key segments? 3 . What part of the budget of my company/organization invest in marketing activities and product innovations? 4 . What gave me the participation in working meetings using the SGDM approach?

${ }^{6}$ In spite of the lack of any previous tourist offer in this commune, thanks to the conducted investments the number of tourists in the commune at present amounts to approximately 100,000 . Source: data obtained from the owners of the above-mentioned attractions. 


\section{BIBLIOGRAPHY}

Baggio, R., Scott, N., Cooper, C. (2010). Improving tourism destination governance: a complexity science approach. Tourism Review, 65 (4), 51-60.

Baker, M.J., Cameron, E. (2008). Critical Success Factors in Destination Marketing. Tourism and Hospitality Research, 8, 79-97.

Barnes, S.J., Mattsson, J., Sørensen, F. (2014). Destination brand experience and visitor behavior: Testing a scale in the tourism context. Annals of Tourism Research, 48, 121-139.

Benčič, M. (2006). Recognizing the importance of tourism's strategy at the local community. Organization - Journal of Management. Information Systems and Human Resources, 39 (2), 141-145.

Beritelli, P. (2011a). Cooperation among prominent actors in a tourist destination. Annals of Tourism Research, 38 (2), 607-629.

Beritelli, P. (2011b). Tourist destination governance through local elites - looking beyond the stakeholder level. Cumulative postdoctoral thesis. University of St. Gallen.

Beritelli, P., Laesser, C. (2011). Power dimensions and influence reputation in tourist destinations: Empirical evidence from a network of actors and stakeholders. Tourism Management, 32 (6), 1299-1309.

Beritelli, P., Bieger, T., Laesser, C. (2007). Destination governance: Using corporate governance theories as a foundation for effective destination management. Journal of Travel Research, 46 (1), 96-107.

Beritelli, P., Reinhold, S., Leasser, Ch., Bieger, T. (2015). The St. Gallen model for Destination Management (SGDM). St. Gallen: St. Gallen University.

Bieger, T. (1998). Reengineering Destination Marketing Organisations: the case of Switzerland. Tourism Review, 53 (3), 4-17.

Bieger, T., Freyer, W. (ed.) (2005). Management von Destinationen. München: Oldenbourg.

Bieger, T., Beritelli, P., Leasser, C. (2009). Size matters! Increasing DMO effectiveness and extending tourism destination boundaries. Tourism Review, 57 (3), 309-327.

Borzyszkowski, J. (2013). Współczesne wyzwania Destination Management Organisations (DMO). Research Works of University of Economics in Wroctaw, 303, 49-57.

Bornhorst, T., Ritchie, J.R.B., Sheehan, L. ( 2010). Determinants of tourism success for DMOs \& destinations: an empirical examination of stakeholders' perspectives. Tourism Management, 31 (5), 572-589.

Buhalis, D. (2000). Marketing the competitive destination of the future. Tourism Management, 21, 97-116.

Byrd, E.T (2007). Stakeholders in sustainable tourism development and their roles: applying stakeholder theory to sustainable tourism development. Tourism Review, 62 (2), 6-13.

Crouch, G.I. (2011). Destination competitiveness: An analysis of determinant attributes. Journal of Travel Research, 50 (1), 27-45.

Czernek, K. (2012). Region turystyczny w ujęciu systemowym a potrzeba współpracy na rzecz rozwoju turystyki w regionie. Turystyka i Hotelarstwo, 18, 9-26.

Debarbieux, B., Oiry Varacca, M., Rudaz, G., Maselli, D., Kohler, T., Jurek, M. (2014). Tourism in mountain regions: hopes, fears and realities. Geneva: UNIGE, CDE, SDC.

Dwyer, L., Edwards, D., Mistilis, N., Roman, C., Scott, N. (2009). Destination and enterprise management for a tourism future. Tourism Management, 30 (1), 63-74.

Elbe, J., Hallén, L., Axelsson, B. (2009). The destination-management organisation and the integrative destination-marketing process. International Journal of Tourism Research, 11 (3), 283-296.
Fedyk, W., Meyer, B., Potocki, J. (2017). Nowa koncepcja zarządzania regionami turystycznymi. Studia Oeconomica Posnaniensia, 5 (4), 50-81.

Fine, C.H. (2000). Clockspeed-based strategies for supply chain design. Production and Operations Management, 9 (3), 213-221.

Galaskiewicz, J. (1995). The making of organizational reputations. University of Minnesota, Mimeo. Unpublished manuscript.

Gretzel, U., Fesenmaier, D.R., Formica, S., O'Leary, J.T. (2006). Searching for the future: challenges faced by Destination Marketing Organizations. Journal of Travel Research, 45 (2), 116-26.

Gunn, C. (1972). Vacationspace: designing tourist regions. Austin: Bureau of Business Research, University of Texas.

Gursoy, D., Saayman, M., Sotiriadis, M. (eds) (2015). Collaboration in tourism businesses and destinations: a handbook. Bingley: Emerald Group Publishing.

Haugland, S.A., Ness, H., Grønseth, B.O., Aarstad, J. (2011). Development of tourism destinations: an integrated multi-level perspective. Annals of tourism research, 38 (1), 268-290.

Keller, P. (2000). Destination marketing: strategic area of inquiry. In: M. Manete, M. Careto (eds), From destination to destination marketing and management. Designing and repositioning tourism products (pp. 29-44). Venice: Ca'Foscarina University.

Kim, H., Richardson, S.L. (2003). Motion picture impacts on destination images. Annals of Tourism Research, 30 (1), 216-237.

Klimek, K. (2013). Destination Management Organisations and their shift to sustainable tourism development. European Journal of Tourism and Hospitality Research, 4 (2), 27-47.

Klimek, K. (2014). State tourism policies in Switzerland and selected good practices for polish tourism. Folia Turistica, 33, 35-61.

Klimek, K., Doctor, M. (2018). Are alpine destination management organizations (DMOs) appropriate entities for the commercialization of summer tourism products? Journal of Destination Marketing \& Management, 10, 181-190.

Laesser, Ch., Beritelli, P. (2013). St. Gallen Consensus on Destination Management. Journal of Destination Marketing \& Management, 2, 46-49.

Lai, P.H., Hsu, Y.C., Wearing, S. (2016). A social representation approach to facilitating adaptive co-management in mountain destinations managed for conservation and recreation. Journal of Sustainable Tourism, 24 (2), 227-244.

Leiper, N. (1990). Tourist attraction systems. Annals of Tourism Research, 17 (3), 367-384.

Myga-Piątek, U., Jankowski, G. (2009). Wpływ turystyki na środowisko przyrodnicze i krajobraz kulturowy - analiza wybranych przykładów obszarów górskich. Problemy Ekologii Krajobrazu, 25, 25-48.

Nestorosk, I. (2012). Identifying tourism potentials in Republic of Macedonia through regional approach. Procedia-Social and Behavioral Sciences, 44, 95-103.

Padurean, L. (2010). Destinations dynamic: a management and governance perspective. Phd Thesis. Lugano: Univesità della Svizzera Italiana.

Pearce, D.G. (1995). Tourism today: a geographical analysis. $2^{\text {nd }}$ edition Harlow: Longman Scientific \& Technical.

Pearce, D.G. (2014). Toward an integrative conceptual framework of destinations. Journal of Travel Research, 53 (2), 141-153

Pechlaner, H., Tschurtschenthaler, P. (2003). Tourism policy, tourism organisations and change management in Alpine regions and destinations: a European perspective. Current Issues in Tourism, 6, 508-539.

Presenza, A., Sheehan, L., Ritchie, J.B. (2005). Towards a model of the roles and activities of destination management organizations. Journal of Hospitality, Tourism and Leisure Science, 3 (1), 1-16.

Richards, G. (2002). Tourism attraction systems: exploring cultural behavior. Annals of Tourism Research, 29 (4), 1048-1064. 
Ritchie, J.R.B., Hudson, S. (2009). Understanding and meeting the challenges of consumer-tourist experience research. International. Journal of Tourism Research, 11, 111-126.

Sheehan, L.R., Ritchie, J.R. (2005). Destination stakeholders exploring identity and salience. Annals of Tourism Research, 32 (3), 711-734.

Świgost, A. (2017). The transformation of the natural environment of the Polish and Ukrainian Bieszczady mountains due to tourism and other forms of human pressure. Current Issues of Tourism Research, 5 (2), 27-35.

Szulc-Dąbrowiecka, E., Żuławska, U. (2015). Zarządzanie regionem turystycznym: przykład regionu Bieszczad w latach 1952-2014. Przedsiębiorczość i Zarzadzanie, 14 (4), 99-112.

UNWTO (2007). A practical guide to tourism destination management. Madrid: World Tourism Organization.
US (2018). Turystyka w województwie podkarpackim w 2017 r. Rzeszów: Urząd Statystyczny w Rzeszowie.

Vengesayi, S. (2003). A conceptual model of tourism destination competitiveness and attractiveness. In: R. Kennedy, Proceedings of the 2003 Conference ANZMAC (pp. 637-647). Adelaide: ANZMAC.

Wolski, J. (2007). Przeksztatcenia krajobrazu wiejskiego Bieszczadów Wysokich w ciagu ostatnich 150 lat (Transformations of the High Bieszczady Mountains rural landscape during the last 150 years). Warszawa: IGiPZ PAN.

Article received:

15 June 2019

Accepted:

30 August 2019 
